\title{
Analisa Hubungan Peran Ganda Wara Terhadap Stres Kerja Sebagai Pendidik dan Tenaga Kependidikan AAU Dalam Era Society 5.0
}

\section{( Relationship Analysis of Wara's Dual Role on Work Stress as Educators and Education Personnel of the Air Force Academy in Facing the Era of Society 5.0 )}

\author{
Garnis Maulidya ${ }^{1 *}$, Sauzan Arjusnana R. ${ }^{2}$, Sherly Aprilia ${ }^{3}$, Gagat Riano ${ }^{4}$, Ismoyo \\ 1,2,3,4,5 Departemen Teknik Manajemen Industri, Akademi Angkatan Udara \\ E-mail: garnismldy12@gmail.com,arjusnana@gmail.com,putriisherrly@gmail.com, \\ gagat.riano@aau.ac.id,bambang.imy@aau.ac.id
}

\begin{abstract}
When career women are not able to balance the two roles, they will experience a conflict known as dual role conflict. On this basis, it is necessary to analyze the relationship between Wara's dual role and work stress as educators and education personnel at the Air Force Academy as part of the readiness of the AAU's role to prepare Indonesian Air Force human resources in the era of society 5.0. The research method used in this study is a correlational quantitative method. The variables in this study are self-adjustment as the dependent variable and the dual role as the independent variable. Based on the research, it can be concluded that dual role conflict has a negative correlation with Wara AAU's work stress due to factors that can reduce work stress, namely setting a reasonable workload, task characteristics that are in accordance with Wara's nature as a woman, strong group cohesion and able to accommodate Wara's needs, as well as AAU's organizational structure and climate followed by leadership policies to provide relatively more flexible working hours, making it easier for Wara to manage carrying out her role as a housewife as well as a woman with a career.
\end{abstract}

Keywords-Airforce Women, AAU, dual role, correlational quantitative method, self-adjustment

Abstrak-Ketika wanita karir tidak mampu menyeimbangkan antara kedua peran maka akan mengalami konflik yang dikenal dengan konflik peran ganda. Atas dasar tersebut perlu dilakukan analisa Hubungan Peran Ganda Wara Terhadap Stres Kerja Sebagai Pendidik dan Tenaga Kependidikan Akademi Angkatan Udara sebagai bagian dari kesiapan peran AAU untuk menyiapkan SDM TNI AU di era society 5.0. Metode penelitian yang digunakan pada penelitian ini adalah metode kuantitatif yang berjenis korelasional. Variabel dalam penelitian ini yaitu penyesuaian diri sebagai variabel terikat dan peran ganda sebagai variabel bebas. Berdasarkan penelitian didapatkan kesimpulan bahwa Konflik peran ganda memiliki korelasi negatif dengan stress kerja Wara AAU dikarenakan adanya faktor-faktor yang dapat mengurangi stress kerja, yaitu pengaturan beban kerja yang wajar, karakteristik tugas yang sesuai dengan kodrat Wara sebagai wanita, adanya kohesi kelompok yang kuat dan mampu mewadahi kebutuhan Wara, serta strutur dan iklim organisasi AAU yang diikuti oleh kebijakan pimpinan untuk memberikan waktu kerja yang relatif lebih fleksibel, sehingga memudahkan Wara untuk memanage melaksanakan perannya sebagai ibu rumah tangga sekaligus wanita yang mempunyai karier.

Kata Kunci-WARA, AAU, Peran Ganda, Metode Kuantitatif Korelasi, Penyesuaian Diri

\footnotetext{
* Penulis Korespondensi (Garnis Maulidya)

E-mail: garnismldy12@gmail.com
} 


\section{Pendahuluan}

$\mathrm{K}$ onsep Society 5.0 merupakan konsep kehidupan masyarakat yang terpusat kepada manusia dan berbasis teknologi. Konsep ini ditujukan agar masyarakat dapat menyelesaikan berbagai permasalahan yang ada dengan memanfaatkan berbagai teknologi dan inovasi yang muncul di era Revolusi Industri 4.0, Big data, Artificial Inteligent (AI) dan Internet of Things (IOT) [1]. Society 5.0 sendiri diperkenalkan oleh Pemerintah Jepang pada tahun 2019, sebagai antisipasi perubahan tata kehidupan secara besar-besaran dan mendasar ke arah yang baru sebagai akibat Revolusi Industri 4.0. Dikhawatirkan perubahan tersebut dapat menghilangkan nilai-nilai karakter kemanusiaan yang dipertahankan selama ini, dan menyebabkan ketidakpastian yang kompleks dan ambigu.

Untuk menjawab tantangan tersebut, diperlukan peran dunia pendidikan di dalam menyiapkan sumber daya manusia (SDM) yang berkualitas dan memiliki kecakapan hidup abad 21, yang dikenal dengan istilah empat C (Creativity, Critical Thingking, Communication, Collaboration). Selain itu individu harus mempunyai kompetensi lainnya seperti kemampuan berpikir kritis, bernalar, kreatif, berkomunikasi, kolaborasi serta memiliki kemampuan problem solving. Dan yang terpenting memiliki perilaku (karakter) yang mencerminkan profil karakter Pancasila, memiliki jiwa kepemimpinan dan memiliki kepedulian sosial serta budaya

Akademi Angkatan Udara (AAU) sebagai salah satu pendidikan kedinasan militer di Indonesia mempunyai peran penting untuk menyiapkan SDM prajurit TNI Angkatan Udara setingkat perwira pertama. Para perwira ini nantinya diharapkan mampu mengemban tugas sebagai prajurit TNI AU serta terus dapat mengembangkan kemampuannya sejalan dengan perkembangan teknologi di era society 5.0. Hal ini telah tersirat dalam sasaran pendidikan yang ditujukan untuk membentuk Taruna yang memiliki sifat Tri Sakti Viratama, yaitu sikap dan perilaku yang dapat diandalkan (tanggon), dapat beradaptasi dengan perkembangan ilmu pengetahuan dan teknologi (Tanggap) serta tangkas dan terampil di bidang latihan jasmani dan kemiliteran (Trengginas) [2]. Untuk itu AAU harus dapat menyiapkan seluruh komponenkomponen pendidikan yang ada di lembaga tersebut, diantaranya tenaga pendidik dan kependidikan.

Pendidik dan tenaga kependidikan adalah dua "profesi" yang sangat berkaitan erat dengan dunia pendidikan, sekalipun lingkup keduanya berbeda. Hal ini dapat dilihat dari pengertian keduanya dimana dinyatakan bahwa Tenaga kependidikan adalah anggota masyarakat yang mengabdikan diri dan diangkat untuk menunjang penyelenggaraan pendidikan. Sementara Pendidik adalah tenaga kependidikan yangberkualifikasi sebagai guru, dosen, konselor, pamong belajar, widyaiswara, tutor, instruktur, fasilitator, dan sebutan lain yang sesuai dengan kekhususannya, serta berpartisipasi dalam menyelenggarakan pendidikan [3]. Oleh karena itu tenaga kependidikan dan pendidik menjadi salah satu faktor utama dan ujung tombak dalam menentukan keberhasilan pendidikan di AAU. Saat ini tenaga kependidikan dan pendidik di AAU diawaki oleh anggota TNI AU, baik militer maupun tenaga sipil, pria dan wanita. Sebagai ujung tombak dalam menentukan keberhasilan pendidikan di AAU, tentunya diharapkan para tenaga kependidikan dan pendidik memberikan kerja maksimal dan mengeluarkan potensi terbaiknya. Harapan ini seringkali menjadi tuntutan kerja yang dapat menimbulkan ketegangan baik secara fisiologis maupun psikologis.

Pada dasarnya pria dan wanita apalagi yang sudah menikah, memiliki beban yang berbeda di dalam sebuah pekerjaan. Beban wanita terjadi karena memiliki dua tantangan yang bertolak belakang. Di satu sisi sebagai pekerja, wanita dapat berkarya dan mengembangkan kemampuannya, namun di sisi lain wanita memiliki tugas dasar sebagai ibu rumah tangga yang harus diembannya yang mana keduanya menuntut tanggung jawab yang tinggi. Ketika wanita karir tidak mampu menyeimbangkan antara kedua peran tersebut maka akan mengalami konflik yang dikenal dengan konflik peran ganda. Simon [4] mengatakan bahwa konflik peran ganda dapat disebabkan oleh beberapa faktor, yaitu tuntutan dari pekerjaan dan keluarga, kesulitan membagi waktu antara pekerjaan dan keluarga, adanya tekanan dari pekerjaan membuat 
seseorang sulit untuk memenuhi kebutuhan keluarga dan kewajiban pekerjaan yang seringkali merubah rencana bersama keluarga. Banyak wanita karir mengakui bahwa secara operasional mereka mengalami kesulitan untuk membagi waktu antara urusan rumah tangga dan urusan pekerjaan. Sehingga salah satu dari perannya menjadi dinomor duakan dan kemudian terbengkalai. Sebagian dari tenaga kependidikan dan pendidik di AAU diawaki oleh anggota militer wanita, yang dikenal dengan nama Wanita Angkatan Udara (WARA). Atas dasar tersebut perlu dilakukan analisa Hubungan Peran Ganda Wara dan Tingkat Stres Sebagai Pendidik dan Tenaga Kependidikan Akademi Angkatan Udara sebagai bagian dari kesiapan peran AAU untuk menyiapkan SDM TNI AU di era society 5.0.

\section{LANDASAN TEORI}

Stres dapat diartikan sebagai suatu kondisi ketegangan yang dapat mempengaruhi emosi, proses berfikir dan kondisi individu [5]. Ketegangan ini timbul karena individu merasakan kekhawatiran, kesulitan dan masalah yang dihadapi terasa berat serta tidak dapat ditoleransi lagi.. Menurut Haeilriegel dan Slocum [6], ada empat faktor utama penyebab stres, yaitu konflik, ketidakpastian, tekanan dari tugas serta hubungan dengan pihak manajemen. Sedangkan Sheridan dan Radmacher [7] serta Gibson, Ivancevich, dan Donnely [8] menyatakan bahwa stres kerja dapat timbul karena dipengaruhi oleh kondisi organisasi, yang meliputi penetapan arah dan kebijaksanaan organisasi, perubahan strategi organisasi, dan tuntutan kerja, tanggung jawab atas orang lain, perubahan waktu kerja, hubungan yang kurang baik antar kelompok kerja dan konflik peran. Konflik peran yang dimaksud disini sering disebut sebagai konflik peran ganda, yaitu sebuah keadaan dimana individu memiliki tanggung jawab atas pekerjaannya dan harus melakukan perannya dalam keluarga, misalnya sebagai seorang ayah ataupun ibu. Hal inilah yang bisa terjadi kepada Wara AAU yang sudah menikah atau berkeluarga, dimana mereka dituntut untuk bisa membagi waktu antara pekerjaannya dengan keluarga.

Frone [9] mengatakan bahwa wanita lebih rentan mengalami depresi dan kecemasan akibat konflik peran ganda. Hal ini berhubungan dengan peran tradisional wanita yang tidak bisa dihindari, yaitu sebagai ibu rumah tangga yang harus mengatur rumah tangga dan membesarkan anak. Hal ini sama seperti yang disampaikan oleh Greenhaus dan Beutell [10] serta Freud dan Bowlby [11] yang menyatakan bahwa konflik peran ganda pada wanita disebabkan rasa tanggung jawab yang lebih besar terhadap keluarga, yang menempatkan peran ibu sebagai aktor utama perkembangan anak. Triaryati (2003) dalam penelitiannya menemukan bahwa wanita pekerja banyak mengalami depresi dan lebih cepat stres dibandingkan pekerja pria, serta sering menjadi korban dalam konflik keluarga (work-family conflict). Konflik peran ganda menjadi faktor utama hal ini terjadi, terutama jika dihubungkan dengan budaya di Indonesia, yang menuntut peran wanita sebagai ibu rumah tangga yang baik dan benar, yang seringkali menimbulkan perasaan bersalah pada wanita. Yasin (2003) menyatakan bahwa secara umum ada tiga tugas utama wanita dalam rumah tangga, yaitu pertama menjadi seorang istri yang dituntut untuk dapat mendampingi suami untuk bersama-sama membimbing keluarga dalam segala kondisi. Kedua menjadi pendidik yang dituntut untuk dapat membina anak-anak yang dimiliki dengan pembekalan kekuatan rohani serta jasmani agar tercipta generasi yang berkualitas. Dan ketiga sebagai ibu rumah tangga, yang dituntut untuk dapat mengelola keluarga agar mempunyai tempat yang nyaman dan teratur bagi seluruh anggota keluarga.

Greenhaus \& Beutell [12] menyatakan bahwa seseorang yang mengalami konflik peran ganda akan merasakan ketegangan dalam bekerja. Konflik peran ini bersiat prikologis, gejala yang terlihat pada individu yang mengalami konflik peran ini adalah frustasi, rasa bersalah, kegelisahan, keletihan. Selanjutnya mereka membagi konflik peran ganda menjadi tiga tipe, yaitu:

1. Time Based Conflict. Yaitu konflik yang terjadi karena waktu yang digunakan untuk memenuhi satu peran tidak dapat digunakan untuk memenuhi peran lainnya,

2. Strain Based Conflict. Yaitu ketegangan yang dihasilkan oleh salah satu peran membuat seseorang sulit untuk memenuhi tuntutan peran yang lain. 
3. Behavior-Based Conflict. Berhubungan dengan ketidak sesuaian antara pola perilaku dengan yang diingkinkan oleh kedua bagian (pekerjaan atau keluarga).

Pada umumnya setiap pekerjaan dapat menyebabkan stress [13]. Hal ini disebabkan karena adanya tuntutan beban kerja yang terlalu banyak, konflik peran dan adanya proses penyesuaian hubungan dengan orang lain. Stres yang terjadi tersebut umumnya merupakan hasil reaksi emosi dan fisik akibat kegagalan individu beradaptasi di lingkungan kerja dimana terjadi ketidak sesuaian antara harapan dan kenyataan. Stress kerja juga dapat diartikan sebagai suatu respon adaptif, dihubungkan oleh karakteristik dan atau proses psikologi individu yang merupakan suatu konsekuensi dari setiap tindakan eksternal, situasi atau peristiwa yang menempatkan tuntutan psikologis dan atau fisik khusus pada individu [14]. Peneliti lain, Nykodym \& George [15] mengartikan stres kerja sebagai rangsangan eksternal yang dapat mengganggu fungsi mental, fisik, dan kimiawi dalam tubuh seseorang menurut. Sedangkan Kavanagh, Hurst, dan Rose [15] mendefinisikan stress kerja sebagai suatu ketidakseimbangan persepsi individu tersebut terhadap kemampuannya untuk melakukan tindakan. Dari berbagai pendapat diatas, dapat disimpulkan bahwa pengertian stres kerja adalah suatu reaksi perasaan tertekan atau keadaan terganggu baik fisik, psikologis, maupun perilaku yang dialami oleh karyawan dalam pekerjaannya.

Wijono [15] menyebutkan terdapat dua faktor yang dapat menyebabkan stress, yaitu:

1. Faktor pekerjaan itu sendiri. Terdiri dari faktor lingkungan (ketidakpastian ekonomi, politis dan teknologi), Faktor Organisasi (Tuntutan Tugas, peran, antarpribadi, struktur organisasi, kepemimpinan, dan tahap kehidupan organisasi) dan Faktor Individual seperti masalah keluarga, masalah ekonomi, dan kepribadian.

2. Faktor Luar Pekerjaan. Terdapat beberapa faktor di luar pekerjaan yang menjadi sumber stres bagi para pekerja, salah satunya yaitu perubahan-perubahan struktur kehidupan. Dalam faktor ini terdapat tiga dimensi struktur kehidupan yang dapat menyebabkan stres, yaitu pertama dimensi budaya sosial yang dilakukan bersama keluarga, religius, keturunan, struktur pekerjaan, dan faktor-faktor sosial yang luas lainnya. Kedua hubungan dengan orang-orang lain dalam dunia budaya sosial, seperti seorang pribadi berperan sebagai suami atau istri, rekan kerja, orang tua, rakyat sebuah negara, dan lain sebagainya. Dan ketiga aspek dari individu itu sendiri. Individu mempunyai kecenderungan ciri-ciri yang tidak tahan terhadap tekanan, ancaman dan mudah cemas.

Beberapa aspek stress kerja menurut Beehr dan Newman [16] adalah sebagai berikut:

1. Fisiologis. Berkaitan dengan perubahan yang terjadi pada metabolisme organ tubuh. Stres kerja banyak berpengaruh pada sistem pembuluh jantung dan perut serta berperan dalam gangguan tidur dan menimbulkan kelelahan fisik yang berlebihan.

2. Psikologis. Yang termasuk dalam aspek ini adalah kecemasan, ketegangan, kebingungan, mudah tersinggung, perasaan frustasi, marah, mudah kesal, emosi menjadi sensitif, perasaan tertekan, kemampuan berkomunikasi menjadi berkurang, menarik diri dan depresi, kebosanan dan kelelahan mental dan menurunnya fungsi intelektual, kurang konsentrasi serta kehilangan spontanitas dan kreativitas.

3. Perilaku. Aspek ini terkait dengan menurunnya produktivitas individu. Gangguan perilaku misalnya bermalas-malasan dan menghindari pekerjaan, kinerja dan produktivitas menurun, meningkatnya ketergantungan pada alkhohol, melakukan sabotase pada pekerjaan, 
makan berlebihan sebagai pelarian, mengurangi makan sebagai perilaku menarik diri dan mungkin berkombinasi dengan depresi, kehilangan selera makan dan menurunnya berat badan, meningkatnya perilaku beresiko tinggi, agresif serta adanya kecenderungan untuk bunuh diri.

Sebagai bagian dari AAU, Wara mempunyai peran dan tanggung jawab yang sama dengan anggota militer pria untuk menyukseskan tugas AAU. Sebagai tenaga kependidikan dan pendidik, aktivitas Wara dapat terbagi menjadi beberapa bagian, yaitu:

1. Bidang Staf. Terbagi menjadi beberapa bagian sebagai berikut:

a. Bidang Polisi Militer. Bidang Polisi militer identik dengan tentara pria. karena berhubungan dengan tugas penegakan disiplin anggota dan menjamin keamanan ksatrian. Wara yang berdinas di bidang ini selain diperbantukan di bagian administrasi, juga memiliki kewajiban yang sama dengan rekan mereka yang pria, untuk menegakkan disiplin dan menjaga keamanan serta ketertiban ksatrian, yang menyebabkan mereka untuk beraktivitas di luar ruangan dan berhadapan dengan banyak anggota lain yang mayoritas adalah pria.

b. Bidang Kesehatan. Bidang ini berkaitan dengan pelayanan kesehatan baik bagi anggota tetat (antap), keluarga dan Taruna. Satuan kesehatan (satkes) AAU merupakan faskes tingkat pertama bagi antap AAU dan keluarga serta Taruna, yang bertugas memberikan pelayanan kesehatan tingkat ringan dan memberikan rujukan lanjut ke RSPAU Hardjolukito, jika dirasa membutuhkan penanganan lebih lanjut. Dalam situasi pandemi covid-19, seluruh anggota satkes termasuk Wara diperbantukan dalam program vaksinasi dari pemerintah. Hal ini tentunya memberikan tekanan stress tersendiri, mengingat tingkat penularan penyakit ini yang cukup tinggi.

c. Aktivitas Wara dalam bidang Administrasi. Bidang ini berkaitan dengan Wara sebagai tenaga kependidikan. Penugasan di bidang ini berkaitan dengan tugas administrasi seperti pembuatan surat-surat dinas dan naskah. serta pengarsipan data-data baik secara hardcopy maupun softcopy. Tingkat stress dapat terjadi diakibatkan pola kerja yang rutinitas dan cenderung monoton.

2. Bidang Pengajaran (Dosen). Wara yang bertugas sebagai Dosen di AAU mempunyai peran utama dalam membentuk Taruna untuk memiliki sifat Tanggap (bidang akademis). Di bidang ini Wara dituntut mampu melaksanakan pembelajaran kepada taruna baik dalam bentuk kuliah/tatap muka, belajar kelompok dan mandiri, praktek di workshop/laboratorium dan strategi pembelajaran berbasis masalah (problem based learning). Tuntutan di bidang ini cukup berat, dihadapkan dengan latar belakang pendidikan Taruna yang tidak seragam dan faktor kelelahan yang dihadapi Taruna dalam mengikuti kegiatan di luar pembelajaran. Hal ini dapat menjadikan tekanan tersendiri yang dapat menimbulkan stres jika tidak disikapi dengan baik.

4. Bidang Jasmani dan Militer. Sebagai pelatih, wara dituntut perannya untuk membentuk Taruna mempunyai sifat Trengginas, yaitu memiliki ketangkasan dalam bertindak dan berolah pikir yang ditunjukkan dengan kesamaptaan jasmani dan daya tahan fisik yang tinggi dalam menghadapi tugas. Aktivitas di bidang ini terkait dengan kegiatan yang lebih ditekankan pada praktek/aplikasi lapangan, dengan sasaran utama membentuk prajurit yang trengginas melalui pemantapan pemahaman dan penguasaan pengetahuan, ketrampilan jasamani dan kemiliteran, guna mendukung pelaksanaan tugas sebagai prajurit Saptamarga. Faktor kondisi fisik taruna 
yang disebabkan kelelahan dan kemampuan stress kerja Wara menjadi tantangan tersendiri di bidang ini, yang jika tidak diantisipasi dapat menimbulkan stres.

5. Bidang pengasuhan. Peran pengasuh disini diaplikasikan dengan menempatkan Wara di Wing Taruna AAU, baik sebagai staf Wing maupun kelompok komando (pokdo) Taruna. Sebagai pengasuh Wara dituntut memiliki peran untuk membentuk Taruna agar mempunyai sifat Tanggon, berupa sifat dan karakter yang Tangguh sebagai calon Perwira dan Pemimpin TNI AU di masa mendatang. Faktor peran ganda dan kemampuan stress kerja Wara yang rata-rata berusia remaja menjadi tantangan tersendiri di bidang ini dan cukup memberikan tekanan stress untuk berperan sebagai pengganti orang tua bagi para Taruna AAU.

\section{Metodologi Penelitian}

Sampel penelitian sebanyak 44 orang Wara yang bekerja di AAU dan sudah menikah. Metode penelitian yang digunakan pada penelitian ini adalah metode kuantitatif korelasional. Variabel dalam penelitian ini penyesuaian diri sebagai variabel terikat dan peran ganda sebagai variabel bebas.

Pengumpulan data dilakukan dengan menggunakan dua skala, yaitu:

1. Peran Ganda. Terdiri dari 40 item pertanyaan yang diadaptasi dari penelitian Nurfatma [17]. Skala ini dibuat berdasarkan dimensi yang terdapat dalam konflik peran ganda yaitu work interference with family dan family interference with work.

2. Stress Kerja. Terdiri dari 35 pertanyaan yang disusun berdasarkan penelitian Waspada [18] yang mencakup aspek-aspek dari stres kerja yaitu aspek gejala fisiologis, psikologis dan perilaku.

Kedua skala diatas disusun dengan model linkert. Item-item skala terdiri dari pernyataan favorable dan pernyataan unfavorable, dengan lima jenis sistem penilaian, yaitu Sangat Sesuai (SS), Sesuai (S), Netral (N), Tidak Sesuai (TS), dan Sangat Tidak Sesuai (STS). Nantinya hasil jawaban responden akan dianalisa dengan metode Product Moment dari Karl Pearson. Proses analisa data dalam penelitian ini dibantu dengan program komputer Statistical Package for Sciene (SPSS) 16.0 for windows.

\section{IMPLEMENTASI Model DAN PEMBAHASAN}

\section{A. Implementasi Model}

Berdasarkan perhitungan yang telah dilaksanakan maka didapatkan hasil sebagai berikut :

1. Uji Realibilitas. Uji reliabilitas pada penelitian ini menggunakan reliability analysis scale (Cronbach Alpha/CA). Berdasarkan uji tersebut, skala peran ganda mempunyai nilai CA sebesar $0,955(>0,70)$. Ini artinya mempunyai realibilitas yang baik. Pada skala peran ganda yang terdiri dari 40 pertanyaan, terdapat 20 yang harus digugurkan (nilai $<0,30$ ). Sedangkan item skala stress kerja yang terdiri dari 20 pernyataan menunjukkan bahwa terdapat terdapat 14 item yang harus digugurkan. Nilai CA stress kerja adalah 0,624, menunjukkan tingkat realibilitas yang tinggi. 
2. Uji Normalitas. Uji normalitas menggunakan metode Kolmogorov-Smirnov, dimana jika nilai sig >0,05 maka data berdistribusi normal. Hasil dapat dilihat pada tabel 1 .

TABEL 1

HASIL UJI NORMALITAS

\begin{tabular}{|c|c|c|c|}
\hline \hline VARIABEL & KOLMOGOROV SMIRNOV $(\mathrm{Z})$ & PROBABILITAS (SIG) & KETERANGAN \\
\hline Peran Ganda & 0.905 & 0.386 & Normal \\
\hline Stress Kerja & 1.103 & 0.175 & Normal \\
\hline Residual & 0.770 & 0.594 & Normal \\
\hline \hline
\end{tabular}

Berdasarkan hasil uji diperoleh nilai Kolmogorov-Smirnov 0,905 (nilai Z pada $\alpha=0,05$ adalah 1,96, Jika $Z_{\text {hitung }}<Z_{\text {tabel }}$ berarti normal)) dengan signifikansi $p=0,159(p>0,05)$ untuk variabel peran ganda dan nilai Kolmogorov-Smirnov 1,103 dengan signifikansi $p=0,200$ untuk variabel stress kerja. Hasil tersebut menunjukkan bahwa variabel peran ganda dan stress kerja memiliki distribusi yang normal. Nilai Residual adalah nilai sisaan dalam hubungan lineritas keda variabel. Dengan nilai Kolmogorov- Smirnov 0.770 dan $p=0.594$ maka residual juga berdistribusi normal.

\section{Uji Linieritas}

TABEL 2

UJI LINIERITAS

\begin{tabular}{|l|l|l|r|r|r|r|}
\hline \multicolumn{2}{|c|}{} & Sum of Squares & df & F & Sig. \\
\hline TOTAL_Y $*$ & Between & (Combined) & 492.385 & 25 & 2.505 & .024 \\
\cline { 2 - 7 } TOTAL_X & Groups & Linearity & 244.382 & 1 & 31.082 & .000 \\
\cline { 2 - 7 } & & Deviation from Linearity & 248.003 & 24 & 1.314 & .279 \\
\cline { 2 - 7 } & \multicolumn{2}{l|}{ Within Groups } & 141.524 & 18 & & \\
\cline { 2 - 7 } & \multicolumn{2}{l|}{ Total } & 633.909 & 43 & & \\
\hline \hline
\end{tabular}

Sumber : SPSS 16

Dari hasil uji terlihat nilai $\mathrm{F}$ pada deviation from linearity menunjukkan nilai 1,314, nilai ini lebih kecil dari nilai $\mathrm{F}$ tabel $(\mathrm{F} 24 ; 18=2,15)$, sehingga peran ganda memiliki hubungan linier dengan penyesuaian diri. Kelinieran ini ini juga ditunjukkan dengan tingkat signifikansi $0,279(>0,05)$.

4. Uji Hipotesa. Hasil analisis menunjukkan besarnya koefisien korelasi antara peran ganda dan stress kerja sebesar $-0,621$ dengan signifikansi $0,000(\mathrm{p}<0,05)$. Hal ini $\mathrm{m}$ enunjukkan adanya pengaruh yang kuat konflik peran ganda terhadap tingkat stress Wara. Pengolahan Data SPSS dapat dilihat pada tabel 3. 
TABEL 3

UJI HIPOTESA

\begin{tabular}{|c|c|c|c|c|c|c|}
\hline \multirow{2}{*}{\multicolumn{2}{|c|}{ Model }} & \multicolumn{2}{|c|}{ Unstandardized Coefficients } & \multirow{2}{*}{$\frac{\text { Standardized Coefficients }}{\text { Beta }}$} & \multirow[b]{2}{*}{$\mathrm{t}$} & \multirow[b]{2}{*}{ Sig. } \\
\hline & & $\mathrm{B}$ & Std. Error & & & \\
\hline \multirow[t]{2}{*}{1} & (Constant) & 30.074 & 1.818 & & 16.544 & .000 \\
\hline & TOTAL X & -.190 & .037 & -.621 & -5.133 & .000 \\
\hline
\end{tabular}

5. Koefisien Determinasi. Dari hasil uji didapatkan nilai koefisien korelasi (R) sebesar 0,621, yang artinya peran ganda memberikan pengaruh yang cukup kuat terhadap stress kerja pada Wara AAU. Sedangkan nilai koefisien determinasi (R Square) adalah 0,386, memberikan arti bahwa peran ganda memberikan pengaruh sebesar 38,6\% terhadap Stres Kerja Wara AAU. Hasil uji dapat dilihat pada tabel 4.

TABEL 4

KOEFISIEN DETERMINASI

\begin{tabular}{|c|c|c|c|c|l}
\hline \hline Model & $\mathrm{R}$ & R Square & Adjusted R Square & Std. Error of the Estimate & \\
\hline 1 & $.621^{\mathrm{a}}$ & .386 & .371 & 3.045 & \\
\hline a. Predictors: (Constant), TOTAL_X \\
\hline
\end{tabular}

6. Penghitungan Mean Empirik. Hasil penghitungan adalah sebagai berikut:

a) Peran Ganda. Pada peran ganda digunakan 20 pernyataan (40 pernyataan dengan 20 item digugurkan). Dengan menggunakan skala satu sampai dengan lima, maka skor minimum adalah $20(20 \times 1)$ dan skor maksimum adalah $100(20 \times 5)$, jarak sebaran data adalah 80 (100-20). Dalam penelitian ini akan digunakan enam wilayah kurva distribusi normal (tiga daerah positif dan tiga wilayah negatif). Untuk itu nilai standar deviasi hipotek didapatkan dengan membagi jarak sebaran dengan jumlah wilayah kurva (80:6), dengan hasil 13,3. Mean hipotek (MH) adalah nilai tengah skala, yaitu 60 (20 x 3), dan mean empirik (ME) adalah rata-rata jawaban responden, yaitu:

$$
M E=\frac{\sum X}{N}=\frac{2.087}{44}=47,4318
$$

Terlihat bahwa rata-rata Wara AAU memiliki peran ganda pada tingkat sedang. Periksa gambar 1.

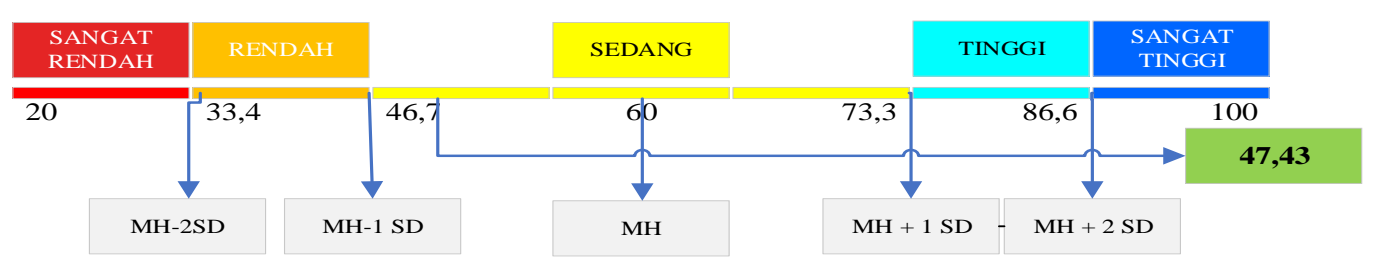

Gambar 1. Kategorisasi Peran Ganda Wara AAU

b) Stress Kerja. Pada skala stress kerja digunakan delapan pernyataan (20 pernyataan dengan 12 item digugurkan). Skor minimum adalah delapan 8 ( 8 x 1) dan Skor maksimum 
adalah 40 (8 x5), dan jarak sebaran data adalah 32 (40-8). Nilai standar deviasi hipotek adalah 5,3 (32: 6). Mean hipotek (MH) 24 (8 x 3), dan mean empirik (ME) adalah:

$$
M E=\frac{\sum X}{N}=\frac{926}{44}=21,046
$$

Didapatkan hasil rata-rata Wara AAU memiliki stress kerja pada level sedang. Periksa gambar 2.

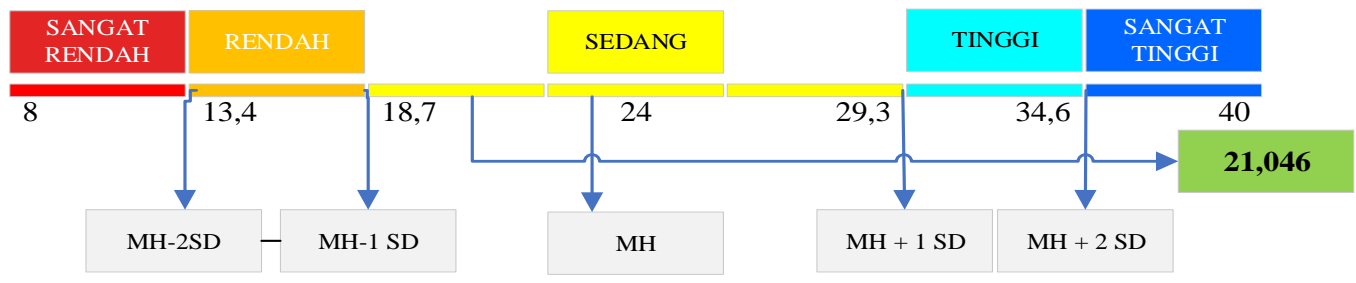

Gambar 2. Kategorisasi Stress Kerja Wara AAU

7. Karakteristik Sampel. Karakteristik sampel dapat dilihat dari tabel 5.

TABEL 5

KARAKTERISTIK SAMPEL PENELITIAN

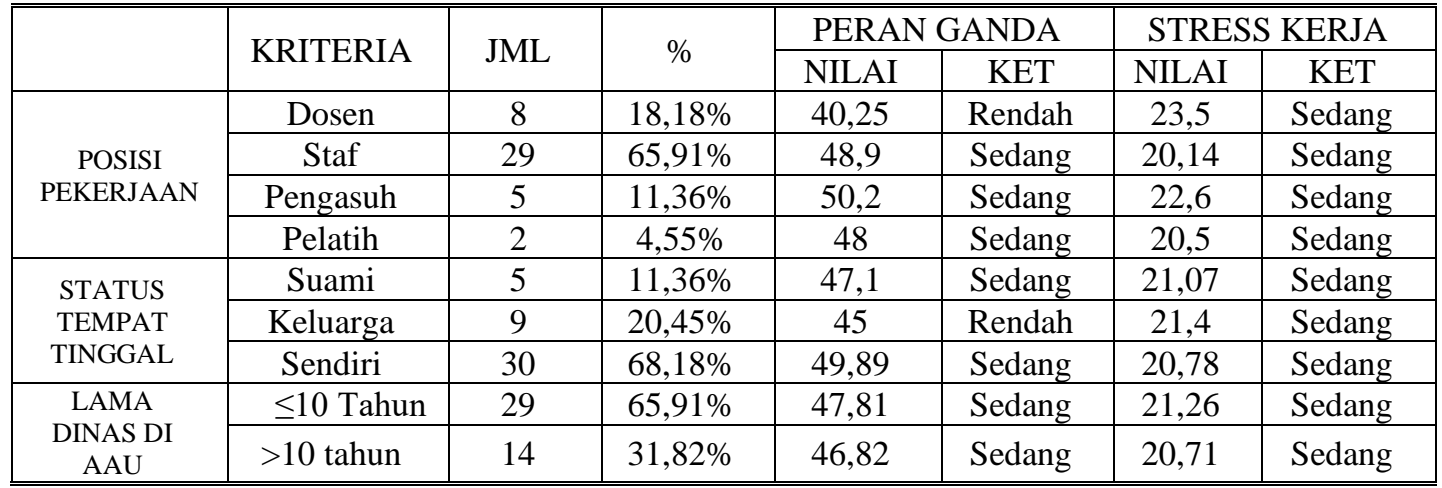

\section{B. Pembahasan}

1. Penelitian ini bertujuan untuk menguji pengaruh peran ganda terhadap tingkat stress kerja Wara yang berdinas di AAU. Berdasarkan uji hipotesa terdapat tingkat signifikan 0,000. Ini menunjukkan bahwa terdapat pengaruh peran ganda terhadap tingkat stress kerja Wara. Nilai korelasi (R) sebesar 0,621, menunjukkan bahwa peran ganda memiliki derajat korelasi kuat terhadap stress kerja Wara sebesar $62,1 \%$. Koefisien determinasi (R square) sebesar 0,386 menunjukkan bahwa peran ganda berpengaruh sebesar 38,6 \% terhadap stress kerja Wara. Pengaruh peran ganda terhadap tingkat stress kerja Wara terjadi karena adanya tuntutan untuk menyeimbangkan tanggungjawab terhadap keluarga maupun pekerjaan [19], dimana aktivitas pada satu peran dapat mengganggu aktivitas pada peran lainnya.

2. Berdasarkan perhitungan mean empirik didapatkan bahwa konflik peran ganda dan tingkat stress kerja Wara berada di level sedang. Penjelasannya adalah sebagai berikut:

a. Posisi pekerjaan. Konflik peran ganda paling besar terjadi pada pengasuh Taruna $(50,2)$ dan terendah pada dosen AAU $(40,25)$. Sebagai pengasuh, membuat Wara 
berkewajiban mengikuti semua kegiatan Taruna di luar waktu kuliah. Hal ini mengharuskan mereka untuk berada lebih lama di luar rumah yang dapat menjadi pemicu munculnya permasalahan. Selain itu ketika ada kegiatan Taruna di luar ksatrian, wara pengasuh mempunyai kewajiban untuk menemani sampai kegiatan tersebut selesai. Hal ini tentunya memberikan tekanan tersendiri yang jika tidak disikapi dengan tepat akan menimbulkan konflik peran ganda [17]. Sedangkan untuk tingkat stress kerja nilai terbesar ada pada dosen AAU $(23,5)$ dan terendah ada pada pekerjaan staf $(20,14)$. Dosen sebagai ujung tombak pembentukan sifat Tanggap Taruna mendapatkan tantangan yang cukup besar terkait dengan latar belakang pendidikan Taruna yang tidak seragam dan faktor kelelahan Taruna dikarenakan kegiatan lain diluar kuliah.

b. Status Tempat tinggal. Bertempat tinggal sendiri akan mengalami konflik peran ganda yang paling besar yaitu 49,89. Hal ini terjadi karena sesuai dengan pendapat Uchino [20], dukungan keluarga memberikan kenyamanan, perlindungan, penghargaan, atau bantuan lain yang tersedia dari keluarga. Semakin tinggi kepedulian dari keluarga maka tingkat konflik peran ganda dapat menurun sehingga mengurangi tingkat stress. Dari hasil penelitian ini terdapat anomali, dimana stress kerja bagi Wara yang tinggal bersama keluarga dari pihak Wara justru memberikan stress kerja yang paling besar.

c. Lama Dinas di AAU. Didapatkan hasil kelompok yang berdinas dibawah 10 tahun memberikan nilai konflik ganda dan stress kerja lebih tinggi dibandingkan kelompok yang berdinas lebih lama. Hal ini sesuai dengan pendapat Panda [21], yang menyatakan salah satu faktor penyebab stress pada peran ganda adalah relasi dengan atasan dan kolega. Waktu dinas yang cukup lama akan membuat hubungan relationship dengan atasan dan para rekan kerja terjalin dengan baik, dan cukup memberikan saling pengertian dan dukungan terhadap kebutuhan Wara, terutama yang berhubungan dengan urusan keluarga.

3. Dari hasil penelitian didapatkan bahwa konflik peran ganda Wara AAU memiliki hubungan terbalik dengan tingkat stress kerja yang dialami. Hal ini dapat dijelaskan sebagai berikut:

a. Jumlah anggota di AAU adalah 819 orang, 587 militer dan 232 PNS. Jika dibandingkan dengan jumlah total anggota, maka jumlah responden adalah 5,3\% atau 7,5\% dari anggota militer, cukup kecil dibandingkan seluruh anggota, sehingga peran Wara di AAU masih dalam taraf wajar dan tidak terlalu berlebihan. Posisi pekerjaan responden pun menunjukkan hanya 34,09\% Wara yang mempunyai tanggungjawab atas Taruna (Dosen, Pengasuh dan pelatih), dengan stress kerja pada level sedang. Hal ini terjadi karena secara realita, hubungan Wara dengan Taruna tidak berlangsung sepanjang waktu kerja Wara tersebut, dan tanggungjawab terbagi secara kelompok dengan anggota AAU lainnya.

b. Pada penelitian ini didapatkan mayoritas responden memiliki konflik peran ganda dan tingkat stress kerja yang sedang. Hal ini disebabkan adanya perasaan emosi dari evaluasi diri atau rasa bersalah pada konflik keluarga maupun pekerjaannya [23]. Individu dengan konflik peran ganda tinggi, tidak mengharapkan kesuksesan dalam berkarier. Karena kesuksesan dalam berkarier akan membuat mereka semakin kesulitan dalam mengatur waktu untuk keluarga. Borelli, dkk [23], menyatakan bahwa dengan banyaknya tugas yang dapat membuat wanita kurang mengurusi anak dan keluarga, akan menimbulkan rasa bersalah kepada kelarga, yang pada akhirnya menimbulkan fear of 
success dalam kariernya. Hal ini dapat terlihat dari lamanya waktu dinas di AAU yang rata-rata lebih dari 10 tahun. Dengan lama waktu dinas di AAU yang lebih dari 10 tahun tersebut, menunjukkan bahwa Wara di AAU mengalami fear of success, dan cenderung nyaman dan menerima kehidupannya saat ini.

c. Secara Struktural, pembinaan Wara di AAU berada di bawah Gubernur AAU sebagai atasan tertinggi. Namun dalam pembinaannya tugas ini didelegasikan kepada Perwira Tertua Wara (Pater) yang umumnya dijabat oleh Wara dengan pangkat tertinggi. Pater Wara bertanggungjawab untuk membina semua Wara dibawahnya melalui pemberian santiaji, diskusi, bimbingan konsultasi maupun kegiatan kelompok lainnya. Hal ini dimaksudkan untuk membentuk kekompakan dan menumbuhkan sikap empati kepada sesama wara. Dengan demikian tingkat stress kerja pada Wara dapat ditekan sedemikian rupa dan disalurkan untuk hal-hal positif [22] dan meningkatkan kinerja Wara untuk mendukung kemajuan organisasi dalam hal ini AAU

d. Sebagai Lembaga pendidikan, kegiatan AAU mayoritas merupakan kegiatan yang berkaitan dengan pendidikan Taruna yang sudah terjadwal tetap untuk sepanjang tahun. Hal ini memudahkan semua anggota termasuk di dalamnya Wara untuk mensinkronkan kegiatan keluarga dengan kegiatan dinas. Hal ini didukung juga dengan kebijakan pmpinan AAU yang memberikan waktu kerja yang lebih fleksibel, asalkan sesuai aturan yang berlaku. Misalnya kemudahan ijin untuk mengikuti kegiatan sekolah anak, ijin ketika ada anggota keluarga sakit dan kewajiban tugas jaga hanya di flat Taruni. Hal ini cukup membantu mengurangi tingkat stress kerja Wara di AAU [12].

\section{KESIMPULAN}

Berdasarkan penelitian didapatkan kesimpulan bahwa peran ganda memiliki korelasi dan pengaruh yang kuat terhadap stress kerja Wara AAU $(R=0,621$ dan $R 2=0,386)$. ME untuk kedua variabel termasuk pada kategori sedang, dengan nilai ME konflik peran ganda di nilai 47,43 dan stress kerja 21,046. Berdasarkan posisi pekerjaan, konflik peran ganda terbesar ada di pengasuh $(50,2)$ dan terendah pada dosen $(40,25)$. Sedangkan tingkat stress kerja terbesar ada pada dosen AAU $(23,5)$ dan terendah ada pada pekerjaan staf $(20,14)$. Berdasarkan status tempat kerja, bertempat tinggal sendiri tanpa ada keluarga Wara ataupun suami akan mengalami konflik peran ganda yang paling besar $(49,89)$ jika dibandingkan dua kelompok lainnya. Berdasarkan lama dinas, kelompok yang berdinas kurang dari 10 tahun akan mengalami konflik peran ganda $(47,81)$ dan stress kerja $(21,26)$ lebih besar dibandingkan dengan kelompok diatas 10 tahun. Konflik peran ganda memiliki korelasi negatif denga stress kerja Wara AAU dikarenakan adanya faktorfaktor yang dapat mengurangi stress kerja, yaitu pengaturan beban kerja yang wajar, karakteristik tugas yang sesuai dengan kodrat Wara sebagai wanita, adanya kohesi kelompok yang kuat dan mampu mewadahi kebutuhan Wara, serta strutur dan iklim organisasi AAU yang diikuti oleh kebijakan pimpinan untuk memberikan waktu kerja yang relatif lebih fleksibel, sehingga memudahkan Wara untuk mengatur waktu di kedua perannya sebagai ibu rumah tangga sekaligus wanita yang mempunyai karier.

\section{UCAPAN TERIMA KASIH}

Ucapan terima kasih kami persembahkan kepada Gubernur Akademi Angkatan Udara yang telah mengijinkan terselenggaranya Seminar Nasional AAU tahun 2021. Dengan terselenggaranya seminar ini sehingga kami dapat menyusun penelitian ini dengan sebaikbaiknya. Tak lupa pula ucapan yang sama kepada seluruh panitia seminar yang telah menyusun kegiatan seminar dengan sangat apik disamping tugas-tugas pokok yang harus dikerjakan. 


\section{REFERENSI}

[1] Direktorat Sekolah Dasar, "Menyiapkan Pendidik Profesional Di Era Society 5.0," 3 februari 2021, 2021.

[2] Akademi Angkatan Udara, Program Taruna Gemilang, 1 ed., Yogyakarta, 2021.

[3] Kemendiknas, "Undang-undang no 20 Tahun 2003 tentang Sistem Pendidikan," 2003.

[4] N. A. P. Laksmi and H. Cholicul, "Hubungan Antara Konflik Peran Ganda (Work Family Conflict) dengan Kepuasan Kerja Pada Karyawati Bagian Produksi PT "X"," Jurnal Psikologi Industri dan Organisasi, vol. 1, no. 02, 2012.

[5] T. H. Handoko, Manajemen Personalia \& Sumber Daya Manusia, 2 ed., Yogyakarta: BPFE, 2012.

[6] S. Wijono, Psikologi Industri \& Organisasi, Jakarta: Kencana Prenada Media Group, 2012.

[7] C. \&. R. S. Sheridan, Health Psychology: Challenging The Biomedical Model, Singapura: John Wiley and Sons, Inc, 1992.

[8] J. Gibson, J. Ivancevich and J. Donnely, Organizations: Behavior, Structure, Processes, Dallas: Richard D. Irwin, Inc, 1994.

[9] J. Y. Roboth, "Work Family Conflict, Stres Kerja dan Kinerja Wanita Berperan Ganda Pada Yayasan Compassion East Indonesia," Journal Riset Bisnis dan Manajemen, vol. 3, no. 1, pp. 33-46, 2015.

[10] J. Greenhaus and N. Beutell, "Sources of Conflict Between Work and Family Roles," Journal Academy of management Review, vol. 10, no. 1, pp. 76-88, 1985.

[11] S. M. Dagun, Psikologi Keluarga, Jakarta: Rineke Cipta, 2002.

[12] N. Triaryati, Pengaruh Adaptasi Kebijakan Mengenai Work Family Issue Terhadap Absen Dan Turnover: Skripsi, Yogyakarta: Universitas Gajah Mada, 2003.

[13] B. Smet, Psikologi Kesehatan, Jakarta: PT. Gramedia Widia Sarana Indonesia, 1994.

[14] J. L. Gibson, Organisasi, Perilaku, Struktur dan Proses, 5 ed., Jakarta: Penerbit Erlangga, 2000.

[15] S. Wijono, Psikologi Industri dan Organisasi, Jakarta: Fajar Interpratama Offset, 2010.

[16] T. Beehr and J. Newman, "Job Stres, Employee Health, and Organizational Effectiveness: Analysis, Model, and Literature Review,", Journal Applied Psychology., 1978.

[17] B. S. Putri, "Hubungan Konflik Peran Ganda Dengan Stres Kerja Pada Anggota Kepolisian Wanita, Skripsi," 2017.

[18] S. Waspada, "Hubungan Antara Makna Kerja Dengan Stres Kerja Pada Anggota Polisi Fungsi Sabhara, Skripsi," Universitas Muhammadiyah , Malang, 2016.

[19] S. Ashfaq, Z. Mahmood and M. Ahmad, "Impact of Work-Life Conflict and Work Over Load on Employee Performance in Banking Sector of Pakistan.," Midle-East Journal of Scientific Research, vol. 14, no. 5, pp. 688-695, 2013.

[20] B. Uchino, A. Vaughn, M. Carlisle and W. Birmingham, "Social Support an Immunity. In S. C Segerstrom (ed.)," in The Oxford Handbook of Psychoneuroimmunology, Oxford University Press, 2012, pp. 214-233.

[21] U. Panda, "Role Conflict, Stress and Dual-Career Couple: An Empirical Study," The Journal of Family Welfare, vol. 57, no. 2, pp. 72-88, 2011.

[22] D. A. Akbar, "Konflik Peran Ganda Karyawan Wanita dan Stress Kerja," Jurnal Kajian Gender dan Anak, vol. 12, no. 1, 2017 Juni 2017.

[23] J. Borelli, S. Nelson, L. River, S. Birken and C. Racusin, "Gender Differences in Work-Family Guilt in Parents of Young Children. Sex Roles," A Journal of Research, vol. 74, no. 3, 2016. 